\title{
A SMALL CLAIMS COURT FOR PENNSYLVANIA
}

\author{
Grorge Scott Stewart, JR.† \\ and \\ Robert D. Abrahams $\ddagger$
}

Two of the principal criticisms directed against the present arrangement of our courts are that the costs are too high in controversies involving small sums of money and that the procedure in such cases is too complicated.

In many states an effort has been made to remedy these defects by the establishment of special courts, of limited jurisdiction, to hear certain cases of small claims only. To date, eighteen states have adopted legislation setting up small claims machinery of one type or another. ${ }^{1}$ In some states in which such tribunals have been set up the court consists of nothing more than a division of an existing court, with the right to file pleadings more informally than is otherwise permitted and a diminution of costs. ${ }^{2}$ In one state an independent court has been set up. ${ }^{3}$

In Pennsylvania, while the machinery of the law is no more cumbersome than that of many other states, there exists among lawyers, nevertheless, much sentiment in favor of simplifying the procedure and decreasing the costs in certain types of small cases. This sentiment is particularly to be

$\dagger$ A. B., Igro, Princeton University; LL. B., I9I4, University of Pennsylvania; member of the Philadelphia Bar; Chief, Municipal Bureau of Legal Aid, I928-1932; Chief Counsel, Legal Aid Society of Philadelphia, 1933 to date; Vice-President, National Áss'n of Legal Aid Organizations.

†L. B., I925, Dickinson Law School ; member of the Philadelphia Bar; Assistant City Solicitor, Philadelphia, I927-I932; Assistant Chief Counsel, Iegal Aid Society of Philadelphia; Consul in Philadelphia for the Dominican Republic; co-author with M. J. Meyer, Esq., of Handook of Pennsylvania Collection Practice; author of various books on non-legal subjects.

I. The acts relating to the establishment of such courts are as follows : CAL. ConE CIV. Pro. (Deering, Supp. I933) §II7; id. (Deering, I93I) at $\$ 927$; Statutes of Cal. I933, c. 743 ; Colo. Comp. Laws (Supp. I932) \$6229I; Conn. Gen. Stat. (I930) \$ 5360 ; Conn. Spec. Acts I927, c. I87 (Stamford) ; Conn. Spec. Acts 1927, c. 319 (Hartford) ; IDAHo CoDE

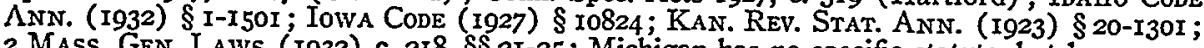
2 Mass. GEN. LAws (I932) c. 2I8, $\$ \$ 2 \mathrm{I}-25$; Michigan has no specific statute, but has a conciliation division established by rule of court; Minn. Laws I917, c. 263 , amended Minn. Laws I929, c. 242 (Minneapolis); Minn. Laws I921, c. 525, amended Minn. Laws I929, c. 346 (St. Paul); Minn. Laws I927, c. I7 (Duluth); NEv. Comp. LAws (Hillyer, I929) $\$ 9364$; N. J. CoMr. STAt. (Supp. I930) \& 6I-22Ia; N. Y. Laws 1934, c. 598; ORE. CodE ANN. (I915) c. 327 ; id. (1930) \$28-1201; R. I. Acts and Resolves 1930, c. I596; S. D. CoMp. Laws (Ig29) \$5228a; Utah Laws I933, c. I6; Vt. Laws I925, No. 43, amended Vt. Laws 1927, No. 44; WASH. REv. STAT. (Remington, I932) § I777-I; Wis. Laws I92I, c. 538 (Milwaukee). Hereafter states will be mentioned without reference to statutes.

2. California (Branch of Municipal Court or, alternately, Justice of the Peace); Colorado (Branch of Justice of the Peace Courts); Connecticut (Branch of City Court) ; Idaho (Justice of the Peace); Iowa (District Court) ; Massachusetts (District Court-in Boston, the Municipal Court); Minnesota (Municipal Court); Nevada (Justice of the Peace); New Jersey (District Court); Oregon (District Court).

3. Kansas. 
noted in the large cities where courts are congested and the machinery of justice is extremely slow. ${ }^{*}$ In Philadelphia, where magistrates have jurisdiction in actions in assumpsit and certain classes of actions in tort, ${ }^{5}$ involving up to one hundred dollars, not only are such actions comparatively costly, ${ }^{6}$ but, because magistrates are laymen, in a large proportion of such cases appeals are taken, whereupon the cases must be tried de novo in the municipal court, with consequent loss of time and additional costs.

Legal aid societies and attorneys representing poor claimants know that in a large proportion of such cases it is not possible for the claimant to advance the necessary costs, and he loses his rights because of his inability to finance their assertion. From the point of view of society, it may be just as important for a man having an honest twelve-dollar wage claim to have a practical means whereby he may assert this claim as it is to give a man having a twelve hundred dollar claim the means of asserting his rights. If, through excessive costs and long delay, you deprive the poor man with the twelve-dollar claim of his money, you also destroy his faith in his right to equal justice under the law. ${ }^{7}$

Small claims courts are of especial importance in industrial communities. In agricultural neighborhooods it is often possible to obtain prompt justice in the court of the local justice of the peace, who, in most cases, knows the parties and acts as mediator, as well as judge. In Pennsylvania, it would probably be impractical to set up uniform small claims courts all over the state. It is suggested, therefore, that a single court be established, to begin with, in Philadelphia, with a proviso allowing cities of the second and third class local option in the matter of setting up small claims courts similar to that to be established in Philadelphia. It is not believed that there is occasion for small claims courts in communities smaller than cities of the third class.

There is at present a movement for the passage of a Small Claims Court Act at the next regular session of the Pennsylvania Legislature. ${ }^{8}$ Some consideration, therefore, based upon the experience of other states, of the limits of jurisdiction of such a court, the agency by which it should be administered, its method of service, the form of its pleadings, trial of cases before it, the method of execution, limits of appeal and costs of proceedings under such a court, is in order.

4. See Report of the Committee on Small Claims, submitted to the Fifth Judicial Conference of Pennsylvania, held at Philadelphia, May I4-16, 1936.

5. PA. Const. Art. V, $\S$ I, II, I2 (Magistrates courts established).

6. $\$ 3.50$ to $\$ 4.00$ for writ of summons; $\$ 1.50$ execution costs; $\$ 1.25$ for transcript of judgment.

7. See Rose, Law and the Little Man (May, 1935) Today 3; Scott, Small Causes and Poor Litigants (I923) 9 A. B. A. J. 457.

8. See supra note 4 . 


\section{JURISDICTION}

Jurisdiction of the small claims courts established in other states, as to the amount in controversy, varies from $\$ 20^{9}$ to $\$ 100,{ }^{10}$ with the majority of the acts calling for $\$ 50$ as the maximum which may be claimed in an action in such a court. ${ }^{11}$ In some states actions for money only may be brought in this court. In one state, the jurisdiction is restricted to suits for money due for wages. ${ }^{12}$ In a number of states jurisdiction is allowed in all cases, whether arising in contract or tort, other than slander or libel. ${ }^{13}$ One state restricts the action to suits founded on book account, ${ }^{14}$ and another allows any claim up to $\$ 50$, except one for the recovery of realty. ${ }^{15}$

Because of the simplification of procedure, which will be discussed later, and because of the absence of a jury in the proceedings, it is suggested that in Pennsylvania the jurisdiction be limited to all actions in assumpsit and to those actions in tort where damages are liquidated. The court should have no jurisdiction in actions for slander, libel, support, divorce, actions involving title to land, criminal actions, the administration of decedents' estates, adoption, guardianship or lunacy. With regard to replevin, the small claims court would be a very useful substitute for the present cumbersome method of replevin ${ }^{16}$ in cases of a non-commercial nature, where the value of the chose is less than $\$ 50$. Such cases arise frequently in matters involving possession of small items of personal property. It is suggested that the small claims court have jurisdiction in replevin whereby the judge of the court may order the bailiff ${ }^{17}$ to take a chose into his possession, the bailiff to store the same until hearing. The hearing could be held within a week of the seizure of the chose by the bailiff, and the chattel awarded then and there to the party entitled to it. By this simplified procedure, the costly process of bond and counter bond would no longer impede a claimant's just right to obtain prompt possession of his personal property.

In addition, certain equity powers ought to be conferred on the court. This would involve no great difficulties, since, under the Pennsylvania system, judges of the law courts are also judges of the courts of equity. There are certain fields of equity, however, in which the small claims court ought

9. In Kansas, Oregon, Vermont and Washington.

10. Colorado, Connecticut, Iowa, Nevada. In Cleveland, Ohio, maximum jurisdiction is $\$$ roo on labor claims, and $\$ 50$ on all others.

Ir. California, Idaho, Massachusetts, Minnesota, New Jersey, New York, Rhode

Island, South Dakota, Wisconsin.

r2. Colorado.

I3. In some states (as in Connecticut, Massachusetts, New York, South Dakota, and Vermont) the jurisdiction in tort is by express statutory provision, and in others by judicial interpretation (California) or by rule of court (Cleveland, Ohio).

14. Rhode Island.

15. New York.

16. See I Smith Laws (Pa. I705) p. 44, § I2; Pa. Stat. Ann. (Purdon, I93I) tit. 12, $\S \S I 824, I 825$.

17. See for method of execution, infra, pp. 22, 23. 
to have no jurisdiction. The court, being not a court of record, should have no power over matters involving title to real estate. There will undoubtedly be a considerable body of opinion among lawyers which would deny to the small claims court any equity jurisdiction at all; but those who, through legal aid work or otherwise, have been in contact with the class of persons who most need a small claims court will realize the necessity for granting at least limited powers in equity to that court. In no case should such powers be exercised where the controversy involves, or might involve, more than a $\$ 50$ limit of jurisdiction, and the interpretation of the limit should be strict. ${ }^{18}$ It is also suggested that a study be made of the results obtained in the states now having small claims court acts requiring that the maximum jurisdiction be fixed at $\$ 50$.

Moreover, in order to keep such a court faithful to its purpose and not to make it a tool of collection agencies, the plaintiff in any action brought in such a court should be a natural person, and not a corporation, partnership, or an association. This suggestion follows the proviso of the New York Act. ${ }^{19}$ Nor should assignees be allowed to bring suit in the small claims court. This is a proviso in the laws of many of the states. ${ }^{20}$

\section{What Agency Should Administer the Act?}

The various small claims court acts differ widely in the agency to which the administration of the act is entrusted. In some states judges of the municipal or district courts are automatically constituted judges of the small claims court, ${ }^{21}$ in others justices of the peace, and in one state a reputable citizen, who may be a layman, is selected by the mayor or county commissioner in each municipality or county. ${ }^{22}$ It is felt that the defects so apparent in the present magistrate system in Philadelphia County would extend to any small claims court in which a layman presided, and it is also believed that the simplification of procedure and denial of the right of appeal under most circumstances, together with the probable absence of counsel in most cases heard in the court, make it essential that a member of the legal profession preside in the Pennsylvania Small Claims Court.

In the experience of other states it has been found that creating new courts is a less satisfactory method of administration than making the small

18. In this connection, see the decisions drawing the line between municipal and common pleas equity jurisdiction in Philadelphia. The municipal court has jurisdiction in equity, as in law, where the amount in controversy does not exceed $\$ 2500$. In certain types of cases not involving a money judgment, it is difficult to determine whether or not the amount in controversy exceeds $\$ 2500$. The decisions in such cases are ruled by the facts. See Pennington v. Conway \& Ash, $92 \mathrm{~Pa}$. Super. I49 (I927) ; Caruso v. Gallo, $62 \mathrm{~Pa}$. Super. 584 (Ig16); Horowitz v. Wohlmuth, 66 Pa. Super. 321 (rgI7) ; Horafeus v. Mangos, $98 \mathrm{~Pa}$. Super. 447 (1929).

19. N. Y. Laws 1934, c. 598, \& I87.

20. California, Colorado, Connecticut, New Jersey, New York, Oregon.

2I. Iowa, New Jersey, New York.

22. Kansas. 
claims court a division of a court already in operation. In Philadelphia the Municipal Court might well be the agency to which to entrust the administration of the proposed small claims court act. ${ }^{23}$ To this end a provision should be made by the Pennsylvania Legislature that in Philadelphia County the Municipal Court shall assign one judge thereof to sit permanently as a judge of the small claims court. Since the Municipal Court handles a very large volume of business, it is suggested that the Municipal Court Act ${ }^{24}$ itself be amended, in order to permit an additional judge to be elected or appointed by the Governor, rather than to assign one from the number of sitting judges.

It would probably be wise to make the office of judge of the small claims court an appointive one, with power of appointment lodged in the Governor, in order to keep the court as free as possible from politics. It is also suggested that an effort should be made in the administration of the proposed small claims court act to keep the overhead as low as possible, in order that the court should not be a great additional expense to the taxpayers of the state. In other counties accepting the small claims court act, it is felt that the court should be a division of the common pleas court or, in Allegheny County, of the county court.

It is significant that, in states where small claims court acts have been adopted, an examination of the cases brought before such courts shows that a very large percentage of them are ones which would have gone to no other court. They are not cases which ordinarily would go before a justice of the peace or magistrate, because the plaintiffs are, for the most part, persons who could not afford the outlay of costs required in such actions. The result of the small claims court legislation is usually not to shift cases from one court to another, but to provide a tribunal to hear certain types of litigation which ordinarily do not get into court at all, and the failure of which to get into court leaves a rankling sense of injustice in the injured party.

\section{Procedure Before the Proposed Court}

Two aims which should be kept in mind, in setting up any small claims court machinery, are to give justice without delay and to provide inexpensive procedure.

The method of speeding up the procedure has differed in many of the states in which small claims courts operate. The various acts differ in the method of serving the defendant and in the pleadings required. In a few

23. There is a Small Claims Division of the Philadelphia Municipal Court, but that division does not hear or decide cases or have a special jurisdiction. No judge sits in that division, and its sole function is to serve as a legal aid unit, and there is no statutory provision for this division.

24. PA. Stat. Ann. (Purdon, r93I) tit. I7, §§68I-699. 
states service by the sheriff, as in ordinary cases, is required; ${ }^{25}$ in others, service by registered mail ${ }^{26}$ or even by ordinary mail, ${ }^{27}$ is permitted. In several states service by telephone is sufficient. ${ }^{28}$ And in some service is permitted on the defendant by the claimant himself.29

In drawing up a method of service of a paper which corresponds to a writ of summons in an ordinary case, it is necessary to balance ease and inexpensiveness of service against possibilities of judgment being obtained without notice to the defendant. It is suggested that probably the most satisfactory method is to permit service by the plaintiff himself upon the defendant, in the same manner as writs of summons are now served by sheriffs or their deputies, in Pennsylvania. Or, if the plaintiff is undesirous of attempting or unable to make such service, service by registered mail, ${ }^{\text {so }}$ plaintiff paying a registry fee of twenty-five cents and the registered letter being sent return receipt demanded, may be allowed, with the right remaining in the judge of the court to have service made by the bailiff of the court in case the judge deems such service wise or expedient. ${ }^{31}$

The office of bailiff of the small claims court, which it is proposed to create in the Small Claims Court Act, will be discussed later in this article. It is suggested that a suit in the small claims court be started by the personal appearance of the plaintiff in the office of the court, where he may fill out a complaint, setting forth his cause of action, in non-technical language, under the supervision of and with the assistance of the court clerk, this complaint to be filled out in duplicate, the original thereof to remain on file with the court and the copy, endorsed with a return day, to constitute the writ served on the defendant. ${ }^{32}$ Attorneys should be allowed to appear in the small claims

25. Iowa, New Jersey, Oregon.

26. California (or personally by claimant), Connecticut, Massachusetts, Minnesota (orally or by telephone or by ordinary mail), Nevada, Rhode Island, South Dakota, Vermont, Wisconsin (or by telephone or sheriff's service).

27. New York, Ohio (Cleveland).

28. Kansas, Minnesota, Wisconsin. Boyd, C. J., in Sharpless Separator Co. v. Brilhart, I29 Md. 82, 90, 98 Atl. 484, 487 (1916), makes the following criticism of service by telephone: "Permitting the writ to be made by telephone opens the door for fraud, confusion and misunderstandings. One desiring to escape service might have someone answer for him, and then contend he was not summoned, or he might truthfully say that he did not know the voice of the officer or did not understand what he said. If the service was questioned, it would oftentimes be difficult for a conscientious officer to sustain his return."

29. That is, in any of the five manners permitted by the Act of IgOr, PA. STAT. ANN. (Purdon, 193I) tit. 12, §29I.

30. That such service would constitute due process seems indubitable. It is a more definite service than that by publication, as presently allowed in divorce proceedings, and
in certain other actions.

3I. Service by registered mail has worked well. The Ninth Report of the Judicial Council of Massachusetts (1933) 19 MASS. L. Q. 7, 95, contains a table which shows that of 1420 notices sent by registered mail from Boston Small Claims Courts in 1932, only two were returned because acceptance was refused, and 82 because the defendant could not be located.

32. The forms for such procedural matters are explicitly set forth in the small claims court statutes of some states (e. g. CAt. CODE Crv. Pro. cited supra note I, Stat. of Cal,, 1933, c. 743). The better practice would seem to be to have such forms prescribed by rule
of court. 
court, but the original statement of claim should be filled out by the plaintiff only, with the assistance of the clerk, at the office of the court, the clerk to have the right to refuse to have the defendant served, if the statement on its face shows no cause of action. This right of refusal is to be subject to review by the judge of the small claims court, to guard against the possibility of a lazy or overly officious clerk. This provision is suggested as a further safeguard against the wholesale filing of claims in this court by attorneys for collection agencies in order to save costs.

No formal answer should be required of the defendant, unless he desires to make a counter claim, in which case his counter claim may not be in excess of \$50. An interesting question has arisen in some states as to the desirability of requiring an answer to be filed if a defense is to be offered. ${ }^{38}$ Some persons believe it saves unnecessary delay at the time of the hearing to require an answer to have been previously filed; others feel that since experience shows that in a large majority of cases the plaintiff prevails because of the lack of a real defense it is better to allow the cases to come to issue without a written defense having been filed and to allow one postponement of the hearing, if it should be necessary for the claimant to produce rebuttal evidence to overcome the defense.

The better view would appear to be to establish that procedure which would require the fewest possible documents, and, therefore, it is suggested that no other pleadings, except the statement referred to above, or a counter claim, be required in order to bring the case to issue, and that the return date set in the statement served on the defendant should be the date when the case should actually be heard. There also should be no necessity to maintain an appearance docket.

\section{TRIAL OF CASES}

Few cases which are properly before the small claims court would require the services of an attorney in presenting them. In a number of states attorneys have been barred from appearing in such courts, ${ }^{34}$ but the prevailing statutory proviso permits persons to appear with their attorneys, or in propria persona, and this would appear to be the better view. ${ }^{35}$

33. See Smith, Small Claims Procedure is Succeeding (1924) 8 J. Ax. Jud. Soc. 247, 250: "It will be noted that the Massachusetts procedure requires the defendant to file an answer (or tell his defence to the clerk who will file it for him) or be defaulted. The arguments pro and con on the point are evenly balanced. By not requiring any answer, you save the defendant one trip to court and you eliminate one procedural step. On the other hand, unless an answer is required, the plaintiff is obliged to attend court often for the sole purpose of being entitled to a default judgment. Furthermore, the answer gives the plaintiff opportunity to prepare for a defense he has not expected."

34. California, Idaho, Iowa, Kansas, Minnesota.

35. See Smith, supra note 33, at 252: "To prohibit the attorney by absolute fiat is a mistake. While reiterating the proposition that in most small claims court cases the attorney has no function to perform, we believe there are some cases where a party is ignorant or frightened or unfamiliar with our language, so that an attorney (the attorney of a legal aid society, for example) might assist the court and facilitate the hearing." 
The small claims court is not a court of record, ${ }^{36}$ in consequence, no stenographer takes down notes of testimony. In this the proceedings are similar to those in the magistrates' courts. The court must have the power to swear witnesses and should have the power of subpona, although it is doubtful whether contempt proceedings should be permitted without certifcation to a court of record.

Trial procedure before the court should be informal, and only the substantive rules of law should be applied by the judge. Questions of evidence should be decided on a purely commonsense basis, and objections to the admission or the exclusion of evidence, or to any purely procedural question, should not be permitted. The court should act as a conciliatory agency, as well as a tribunal, and an effort should be made to satisfy both parties to a controversy, where there is a real question between the parties.

Trial of cases should not be protracted, however. Witnesses should be subpœnaed only by the court itself, where the judge hearing the case feels that the presence of a particular witness is necessary to enable him fairly to decide the issue.

Continuances should be permitted by the judge only under two circumstances:

I. Where one of the parties is unable to be present through actual illness or some other valid reason.

2. Where a defense is produced which was not foreseen by the plaintiff, and where the judge feels that the plaintiff ought to have an opportunity to rebut the defense.

There should be no set speeches either by counsel or the litigant. Both parties should be questioned by the judge, rather than by counsel, and all formal proceedings should be eliminated. The sitting judge should decide the case immediately following the hearing and should notify the parties of his decision orally while they are still in court, at the same time having his finding recorded by writing the same, over his signature, in a space to be provided on the original form containing the plaintiff's statement of claim.

\section{Method of Execution}

It is suggested that in the Pennsylvania Act a proviso be made for a court officer, to be known as bailiff, whose duty it will be to serve the court, both in making service of the original process, where the court deems such service by its own officer necessary, and in executing the judgments of the court. This bailiff should be paid a yearly salary, in order that he should not be dependent upon fees and, therefore, subject to the temptation of ac36. That is, no record of testimony is to be sent up to a court of appellate jurisdiction
upon appeal thereto. 
cepting honorariums either from the plaintiff, for prompt service, or from the defendant, for delay.

To prevent this officer from becoming a mere salaried official, who, with human nature what it is, might do as little as possible and thereby lessen the efficiency of the court, it is suggested that, in addition to his salary, the bailiff should be entitled to certain small commissions payable out of receipts from defendants on execution. The bailiff's commissions should be added to the amount due, plus a nominal charge of about twentyfive cents for the execution, but both this charge and the bailiff's commission should be payable only after the plaintiff's judgment, plus interest, has been satisfied, thus giving the bailiff an incentive to collect the full amount of the court's judgment and making it possible to charge the bailiff's fee and execution at the real expense of the defendant, rather than that of the plaintiff. Very often, at present, sheriff's or constable's costs, while nominally assessed against the defendant, must in fact be partially paid by the plaintiff, where the sheriff or constable is unable to collect.

Following the entry of a judgment for the plaintiff, under the small claims court act in all of the states at present having such acts, the ordinary method of execution through constable or sheriff is mandatory. In a few states it is necessary to certify the judgment over to a court of record. ${ }^{37}$ In other states the act simply prescribes that the usual execution process is to issue as in all other courts of the state. ${ }^{38}$ It has been found that much of the usefulness of small claims courts is mitigated by reason of the expense and difficulty of executing their judgments. This would be especially true in Pennsylvania, where execution costs are high. ${ }^{39}$

The bailiff should be bonded against the possibility of his misfeasance or malfeasance, and he should not be permitted to engage in any other business than that for which he is paid by the court. In this he would differ from a constable, who frequently engages in the collection business or some other activity in addition to that of the court from which he is accredited. Should the bailiff fail to realize enough to satisfy the judgment on execution, it should be possible to transcribe such judgment to the ordinary judgment docket of the local court of record of minimum jurisdiction for a very small additional cost, about fifty cents, and from that point on it should be possible to issue execution through the sheriff in the ordinary manner, following the practice now used on transcripts from judgments of magistrates or justices of the peace courts.

37. Kansas, Minnesota, New Jersey.

38. Or, as in the New York statute, no reference at all is made to execution. So also is South Dakota, Ohio (Cleveland), Vermont, Washington, and Wisconsin.

39. See Sheriff's Fee Bill, Pa. Laws I933, p. II4I. 


\section{Right OF APPEAL}

The question of appeals is an important one in considering the practicability of a small claims court. Should appeal be easy and inexpensive, the purpose of the court may be frustrated; defendants might subject plaintiffs to unnecessary delay, and additional loss of time for appearance in court.

The small claims statutes of the various states vary in the rights of appeal granted. In some states either party may appeal to a court of record. ${ }^{40}$ In others no right of appeal whatever is granted. ${ }^{41}$ In still others no appeal by the plaintiff is permitted, but the defendant may appeal to a court of record, after filing a bond for the amount at issue, plus certain costs and sometimes an attorney's fee. ${ }^{42}$ In the New York statute an appeal is allowed only on questions of law. It is not believed that denying the right of appeal, either wholly or in part, would make the proposed Pennsylvania statute unconstitutional. As the law now stands in Pennsylvania, appeals in a case involving less than $\$ 5.33$, on judgments of magistrates and justices of the peace, are not permitted. ${ }^{43}$

To allow an appeal on the facts from judgments of the proposed small claims court would mean a trial de novo in a court of record, with the consequent delay. It is therefore suggested that the right of appeal be denied to both parties in any action in the small claims court, but that a right be granted to bring in the record by certiorari lodged in the court of record of minimum jurisdiction of the county, at which time the proceedings should be similar to those on certiorari from magistrates or courts of justices of the peace, and only defects apparent on the face of the record should permit reversal. It should be possible, however, for a defendant to transfer a case from the small claims court to a court of record of minimum jurisdiction of the county, before a hearing, where the defendant desires a jury trial. In such cases, in order to prevent transfer for the mere purpose of delay, the defendant should be required to pay a jury fee of $\$ 4$, plus a substantial transfer fee of about $\$ 5$, and in addition should be required to post bail absolute for the whole amount of the judgment and costs, all this to be done at least forty-eight hours prior to the hearing. Notice should be served on the plaintiff at least twenty-four hours prior to the hearing, in order to prevent his unnecessary appearance in court, and in addition, as it will become necessary for the plaintiff to be represented by an attorney if the case is transferred to a court of record, a proviso should be made for a statutory

40. Colorado, Iowa, Minnesota, Nevada, New Jersey, Ohio (Cleveland), Washington, Wisconsin.

4I. Connecticut, Massachusetts, Vermont.

42. California, Idaho, Kansas, Oregon, Rhode Island.

43. See Workmen's Compensation Act, Pa. Stat. Ann. (Purdon, i93I) tit. 77, \$872, whereby right of appeal from findings of board is limited to questions of law. 
attorney's fee of \$Io, which should also be required to be posted in advance by the defendant.

If the defendant prevails at the trial of his action in the court of record, he should obtain a judgment carrying, in addition to costs, the jury fee and transfer fee, and also receive a refund of the attorney's fee posted, the purpose of a judgment against the plaintiff carrying these costs being to discourage unworthy plaintiffs from bringing their claims in small claims courts under threat of transfer and subsequent judgment against them for costs.

No question of a violation of the right of trial by jury, as granted by the Pennsylvania Constitution, Article I, Section 6; would arise in actions brought in the small claims court. If the defendant failed to appear at all, the plaintiff would be entitled to judgment for want of a defense, as he is at present in any proceeding, obtaining such judgment. If the defendant appears, he may have a jury trial by going through the above process of transfer. If the defendant chooses not to transfer, but to appear before the small claims court, it would be necessary for him to sign a waiver at the time of his appearance which would be printed on the docket form. If he physically appears, but refuses to sign the waiver, he can be apprised of his right to transfer by the court, and if he refuses thereafter either to sign a waiver or to transfer, it is believed that judgment could thereupon be entered against him for want of a defense, and there would be no violation of his constitutional right. ${ }^{44}$

\section{Costs}

In order to make the work of a small claims court effective, costs must be held to a minimum, excepting costs of appeal for a transfer to a court of record. Costs under the small claims courts now in force in a number of states vary. In some states no costs whatever are paid; the usual requirement is that a fee of $\$ \mathrm{I},{ }^{45} \$ \mathrm{I} .25$, $^{46}$ or $\$ \mathrm{I} .5 \mathrm{O}^{47}$ be paid by the plaintiff at the time of commencing his action. In some states there is no charge for the service of the process, or, as before noted, the service may be made by the

44. As to amounts in controversy of $\$ 5.33$ or less, it is probable that no waiver would be necessary, as by Act of March 20, 1810, 5 SMrrm LAws p. I6I, $\$ 3$, there is no appeal from a judgment of a justice of the peace, unless it exceeds the sum of $\$ 5.33$. As this act antedates the constitution, there is no question of its validity, as Art. I, $\$ 6$ of the constitution states only "trial by jury shall be as heretofore, and the right thereof remains inviolate." As to amounts exceeding \$5.33, it would work no undue hardship on a defendant seeking a jury trial to make the necessary transfer. The right of jury trial, however, cannot be waived by implication, and it is for this reason that it would be necessary to obtain a signed waiver. In the writer's opinion, making such a waiver a condition of presenting a defense in a small claims court would effectively prevent any constitutional objection. ington.

45. California, Colorado, Connecticut, Massachusetts, New Jersey, Vermont, Wash-

46. Rhode Island, New York.

47. Idaho. 
plaintiff himself, or by mail. In others there are added costs of service, ranging from twenty-five cents ${ }^{48}$ to the regular service costs for other forms of writs. ${ }^{49}$ Under many of the acts costs of execution must be added when execution is desired. ${ }^{50}$ It would seem undesirable to make it possible to file suit in the proposed court without any costs at all, as this would encourage needless litigation. A charge should be made but it should not be so high as to prevent any person having a just claim from receiving relief.

Costs for obtaining a certiorari should be the same for both plaintiff and defendant. It is suggested that the costs of filing the statement, which will commence a suit be $\$ \mathrm{I}$, plus a charge of twenty-five cents if the service is to be made by registered mail, or fifty cents if the service is to be made under the court's direction by the bailiff. No cost for execution should be required of the plaintiff in any case but the bailiff should be permitted to add the ordinary execution costs in satisfying the judgment, ${ }^{51}$ such costs to be payable by defendant, together with interest on the judgment and bailiff's commission, as above noted.

As already indicated in the course of the present article, these suggestions for the procedure and administration of a Pennsylvania small claims court have been propounded on the basis of a thoughtful comparison of the many small claims statutes now in operation in other states. While they perhaps do not constitute a perfect model for adoption, it is to be hoped that they may possibly serve as the groundwork for discussion and legislative action in this state in the very near future. ${ }^{52}$

48. California, Connecticut (50 cents).

49. Iowa.

50. California, Connecticut, Idaho, New Jersey, New York, Rhode Island. gence.

5I. This proviso is intended to encourage the bailiff to press the execution with dili-

52. For further discussion and analysis of the problems of small claims litigation see Alper, Practice in the Small Claims Court of the City of New York (ro34) 9 Sr. Jors's L. REv. 247; Clark and O'Connell, The Working of the Hartford Small Claims Court (1929) 3 Conn. B. J. I23; Fernow, Proposed Small Claims Branch of the City Court of Buffalo (I929) 2 LINCOLN L. Rev. 36; Maguire, Pajerty and Civil Litigationi (I923) 36 HARv. I. REv. 36r ; Maguire, Justice for the Poor (1923) $6 \mathrm{~J}$. AM. Jud. Soc. I79; Nehemkis, The Boston Poor Debtor Court: A Study in Collection Procedure (I933) 42 YALE L. J. 56I; Pound, The Administration of Justice in the Modern City (IgI3) 26 HARv. I. REv. 302; Scott, Small Causes and Poor Litigants (1923) 9 A. B. A. J. 457. 